\title{
Cytokinin Induction in Response to Tomato Pinworm, Tuta absoluta Meyrick (Gelechiidae: Lepidoptera) Damage on Tomato Leaves
}

\author{
K. Murugasridevi ${ }^{1}$, S. Jeyarani ${ }^{1 *}$ and S. Mohan Kumar ${ }^{2}$ \\ ${ }^{1}$ Department of Agricultural Entomology, Centre for Plant Protection Studies, Tamil Nadu \\ Agricultural University, Coimbatore-641 003, Tamil Nadu, India \\ ${ }^{2}$ Centre for Plant Molecular Biology and Biotechnology, Tamil Nadu Agricultural University, \\ Coimbatore-641 003, Tamil Nadu, India \\ *Corresponding author
}

\section{A B S T R A C T}

\begin{tabular}{|l|}
\hline Ke y w o r d s \\
$\begin{array}{l}\text { Tuta absoluta, } \\
\text { Cytokinin, Nutrient } \\
\text { acquisition }\end{array}$ \\
\hline Article Info \\
\hline $\begin{array}{l}\text { Accepted: } \\
\text { 22 July 2019 } \\
\text { Available Online: } \\
\text { 10 August } 2019\end{array}$ \\
\hline
\end{tabular}

Keywords

Tuta absoluta, Cytokinin, Nutrient acquisition

Article Info

Accepted:

Available Online:
Endophagous herbivorous insects live and feed within plants and lead to the formation of different plant architectures like galls and mines which offers protection from natural enemies. This selective feeding behaviour of the endophagous leaf miner pests is also known to alter plant physiology by manipulating the plant phytohormonal balance for exploiting the plant resources effectively. Cytokinins (CKs) are one of the phytohormones that play a key role in plant morphology, plant defense and leaf senescence. The results of the present experiments with one of the invasive leaf mining pest, the tomato pinworm, Tuta absoluta Meyrick (Gelechiidae: Lepidoptera) revealed higher cytokinin content in mined leaves that are presumed to be responsible for maintaining the nutritive green tissues than unmined leaves which otherwise will undergo senescence.

\section{Introduction}

Endophagous herbivorous insects live within plants and lead to the formation of plant architectures like galls and mines. These insect derived architectures offer protection from natural enemies, extreme environmental conditions and also enable the resident to feed selectively on tissues with high nutrient content and low defense responses (Stone and Scho“nrogge 2003). Tomato pinworm, Tuta absoluta Meyrick (Gelechiidae) is one of the most devastating endophagous leafminer pests of solanaceous crops. It mines on the mesophyll region by destroying the epidermal region and causes 14.4 to 97.9 per cent yield loss (Kumari et al., 2015). These endophagous insects are also known to alter plant primary or secondary metabolisms and thereby they also control their chemical properties (Stone and Scho"nrogge 2003). Several hypotheses have been suggested on the adaptive 
significance and the evolution of this concealed feeding behaviour. The mines provide shelter from the detrimental effects of the physical environment and offers protection from natural enemies (Pincebourde and Casas, 2006; Pincebourde et al., 2006). Interestingly, leafminers are known to select the leaf tissues with high nutritional content and low chemical and structural defense content (Connor and Taverner, 1987).

As the leaf miners develop inside a confined space with restricted availability of nutritive tissues, they might also act against the change in leaf physiology such as premature leaf abscission or leaf senescence.

Englebrecht et al., (1969) reported that the leafminer infestation results in the formation of 'green islands' that are characterized by photosynthetically active green patches around larvae in senescing yellow leaves. Cytokinins $(\mathrm{CKs})$ are one of the phytohormones that play a key role in plant morphology, plant defense, inhibition of senescence, regulation of cell division and enable the insects to withdraw plant resources for their own advantage (Meldau et al., 2012; Giron et al., 2013).

Giron et al., (2007) and Kaiser et al., (2010) reported large accumulation of cytokinins in mined tissues, which is responsible for the preservation of functional nutrient rich green tissues at a time when leaves are otherwise turning yellow. It is also reported that the Cytokinin accumulation is not only seen on green leaves with mines but also on yellow leaves with mines.

These results suggest a continuous production or accumulation of Cytokinin in mined areas with the phenomenon tightly linked to the presence of the mining insect. In this view, we conducted experiments to confirm and quantify the cytokinin induction in tomato leaves mined by T. absoluta.

\section{Materials and Methods}

The induction of cytokinin in mined leaf samples were analyzed by following the method described by Giron et al., (2007).

\section{Leaf Sample preparation}

The leaf samples for the cytokinin quantification were obtained from the tomato pinworm culture maintained at the Insectary Unit of the Department of Agricultural Entomology, Tamil Nadu Agricultural University, Coimbatore. One gram of tomato leaf samples (PKM 1) of un-mined and mined (first, second, third and fourth instar) (Fig.1a 1d) green leaves and yellow leaves were lyophilized with liquid Nitrogen, pulverized and extracted overnight by adding $5 \mathrm{ml}$ of HPLC grade methanol.

\section{Purification}

The samples were centrifuged at $6000 \mathrm{rpm}$ for 10 minutes. The supernatant was collected and the extract was passed through anhydrous sodium sulphate $(1 \mathrm{~g} / 4 \mathrm{ml})$ to remove the moisture. The extract was subsequently concentrated near to dryness by vacuum evaporation (Roteva \# 8763 RD, M/s Media Instrument, Mfg., Co., Mumbai) at $40^{\circ} \mathrm{C}$. The residue was re-dissolved in $1 \mathrm{ml}$ of HPLC grade methanol and filtered through $0.2 \mu \mathrm{m}$ filter and stored in refrigerator at $4^{\circ} \mathrm{C}$ for HPLC analysis. Each treatment was replicated thrice.

\section{Preparation of standard stock solution of Trans-riboside zeatin}

Accurately weighed $5 \mathrm{mg}$ of Trans-riboside zeatin (Sigma-Aldrich, India) was transferred to volumetric flask containing $40 \mathrm{ml}$ of methanol (HPLC grade), dissolved properly and volume made upto $50 \mathrm{ml}$ to give a stock solution concentration of $100 \mathrm{ppm}$ and the 
standard stock solutions was stored at $-20^{\circ} \mathrm{C}$ in dark and used to prepare the working standards of different concentrations. The concentration range of working standard solutions for calibration curve was $0.05 \mathrm{ppm}$, $0.1 \mathrm{ppm}, 0.2 \mathrm{ppm}, 0.4 \mathrm{ppm}, 0.8 \mathrm{ppm}$ and 1 ppm. The correlation of calibration curves was 0.99 for trans-riboside zeatin. Different sets of working standards were injected as duplicates into the HPLC systems. All the standards prepared were stored at $-20^{\circ} \mathrm{C}$ in darkness.

\section{HPLC Analysis}

The quantification of cytokinin in tomato leaves were achieved by HPLC-DAD system (Agilent 1220 Infinity II LC of Agilent Technologies Co., USA) including a binary pump, an auto-sampler, temperaturecontrolled column oven and a diode array detector (DAD). The separation was carried out on a reverse-phase C18 column (150 mm x $4.6 \mathrm{~mm}$ i.d., $5 \mu \mathrm{m}$ ) with the chromatographic conditions of $10 \mu \mathrm{l}$ injection volume, $35^{\circ} \mathrm{C}$ column temperature, UV detection wavelength of $254 \mathrm{~nm}$ and a mobile phase consisted of methanol and Milli-Q water (40/60, v/v) with a flow rate of $1.0 \mathrm{ml} / \mathrm{min}$ and the total run time set as ten minutes. Data analysis was performed in Minitab 17 statistical software.

\section{Results and Discussion}

The extracts of green tomato leaves with different stages of $T$. absoluta mining, healthy green leaves and old yellow leaves injected into the HPLC systems yielded the fractions at 4.13 minutes for trans-riboside zeatin (Fig. 2). Among different samples, T. absoluta infested leaves had higher concentration of cytokinin viz., $4.29 \pm 0.13,4.41 \pm 0.17,4.66 \pm 0.26,5.37$ \pm 0.12 ppm respectively for first, second, third and fourth instar mined leaves. In addition, the healthy green leaves had cytokinin concentration of $2.64 \pm 0.15 \mathrm{ppm}$ and yellow leaves with $0.95 \pm 0.16 \mathrm{ppm}$ (Fig. 3).
Cytokinin content increased with the progressive larval instars compared to the unmined green leaves. The present study is in accordance with previous reports of Giron et al., (2007) who reported increased cytokinin content in mined areas than the un-mined green leaves and decrease in the level of cytokinin with leaf senescence. Zhang et al., (2017) reported that the green leaves with mines showed higher cytokinin content in comparison with the green leaves without mines.

Certain lepidopteran species in the families Gracillaridae (Miller, 1973), Tischeriidae (Osborne,1973) and Dipteran family, Agromyzidae (Kahn and Cornell,1983) produced green islands which were distinguished by stay-green phenotype of mined areas with higher cytokinin content while other regions of the same leaf turned yellow. However, the tomato pinworm, $T$. absoluta prefers to feed young green tissues only. In addition, T. absoluta larval incidence is not noticed in old senesced leaves as that of other leafminers such as Stigmella argentipedella, Stigmella argyropeza (Engelbracht, 1971), Phyllonorycter blancardella (Giron et al., 2007). Our results also suggests that by way of continuous production and accumulation of Cytokinin in mined areas, the $T$. absoluta could delay the senescence for retaining the leaves green. This is in corroboration with the findings of Body et al., (2013) who confirmed that the leafminer caterpillar, Phyllonorycter blancardella, with the assistance of endosymbiotic bacteria, modifies phytohormonal profiles, not only on senescing (photosynthetically inactive) but also on normal (photosynthetically active) leaf tissues of its host plant (Malus domestica). This leaf physiological manipulation allows the insect to maintain sugar-rich green tissues and to create an enhanced nutritional microenvironment in an otherwise 
degenerating context. It also allows them to maintain a nutritional homeostasis even under distinct leaf environments. The origin of these cytokinins is however currently unknown and several hypotheses can be proposed. To unveil, initially, high levels of cytokinins in mined areas may be the result from the over expression of the plant genes which produce cytokinins in the infected zone. Oral secretions of feeding insects contain many specific compounds able to interact with plant gene expression as shown in the upregulation of plant defences (Arimura et al., 2005). In addition, cytokinins in leafminer infested tissues could result from an accumulation process rather than a synthesis intrinsically. Feeding activity of leafminers is known to alter biophysical properties of leaves and consequently respiration and transpiration rates (Pincebourde et al., 2006). Such processes strongly impact the flow of nutrients within a leaf and could potentially result in the accumulation of cytokinins in mined areas (Engelbrecht et al., 1969).

Fig.1 Damage symptom caused by different instars of $T$. absoluta on tomato leaves

Fig.1a.First instar

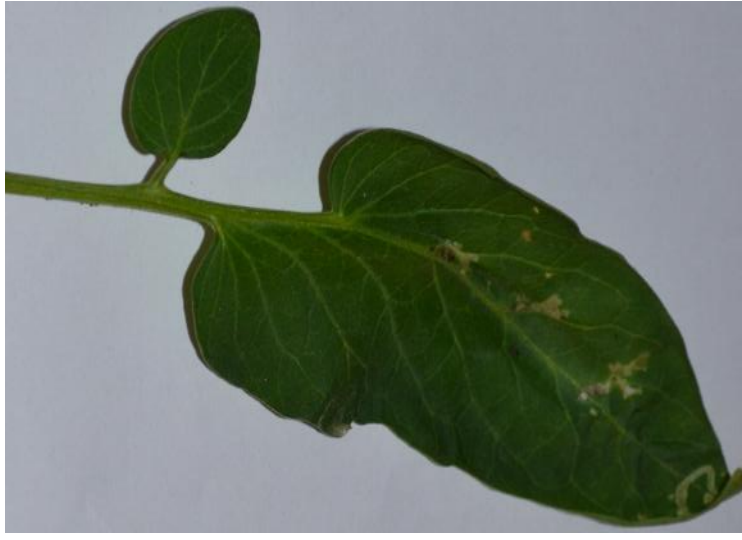

Fig.1c. Third instar

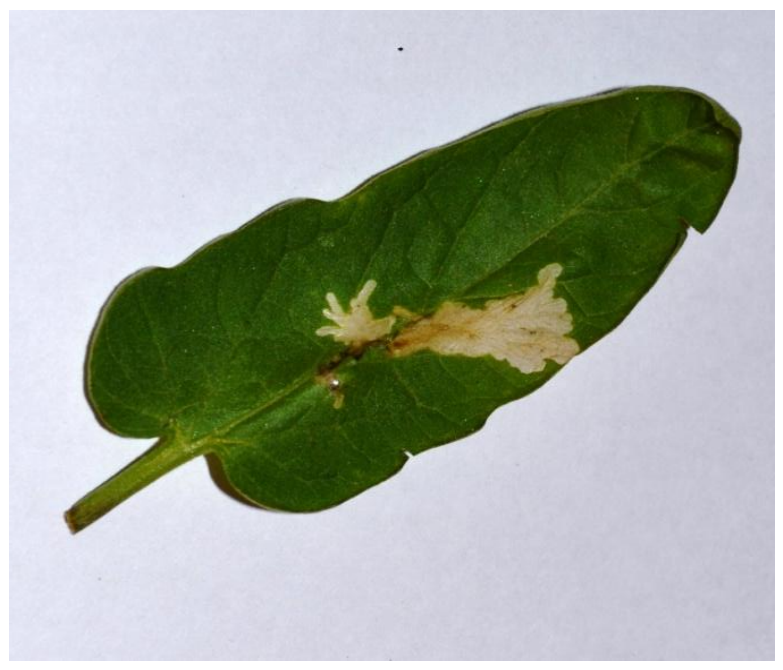

Fig.1b.Second instar

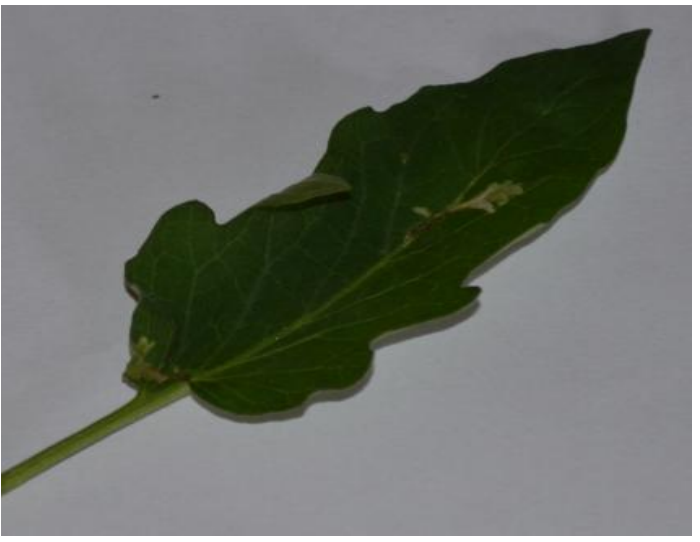

Fig.1d. Fourth instar

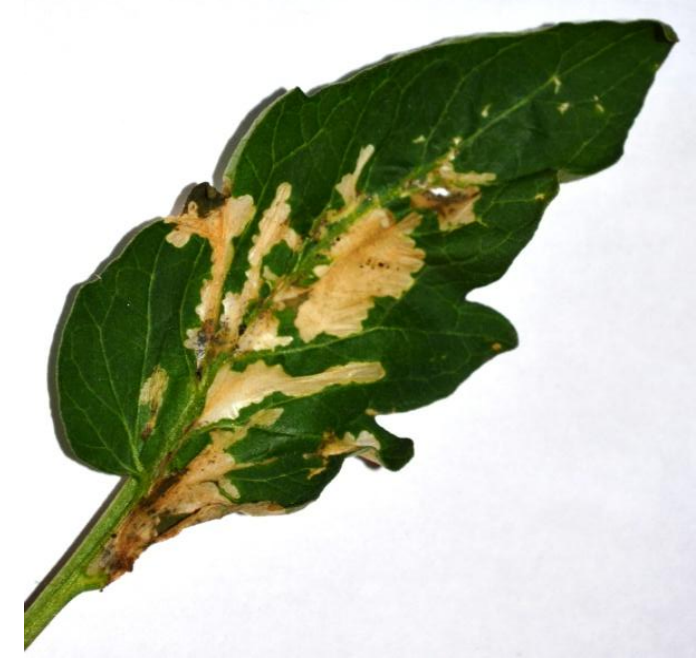


Fig.2 HPLC separation of Trans riboside-zeatin

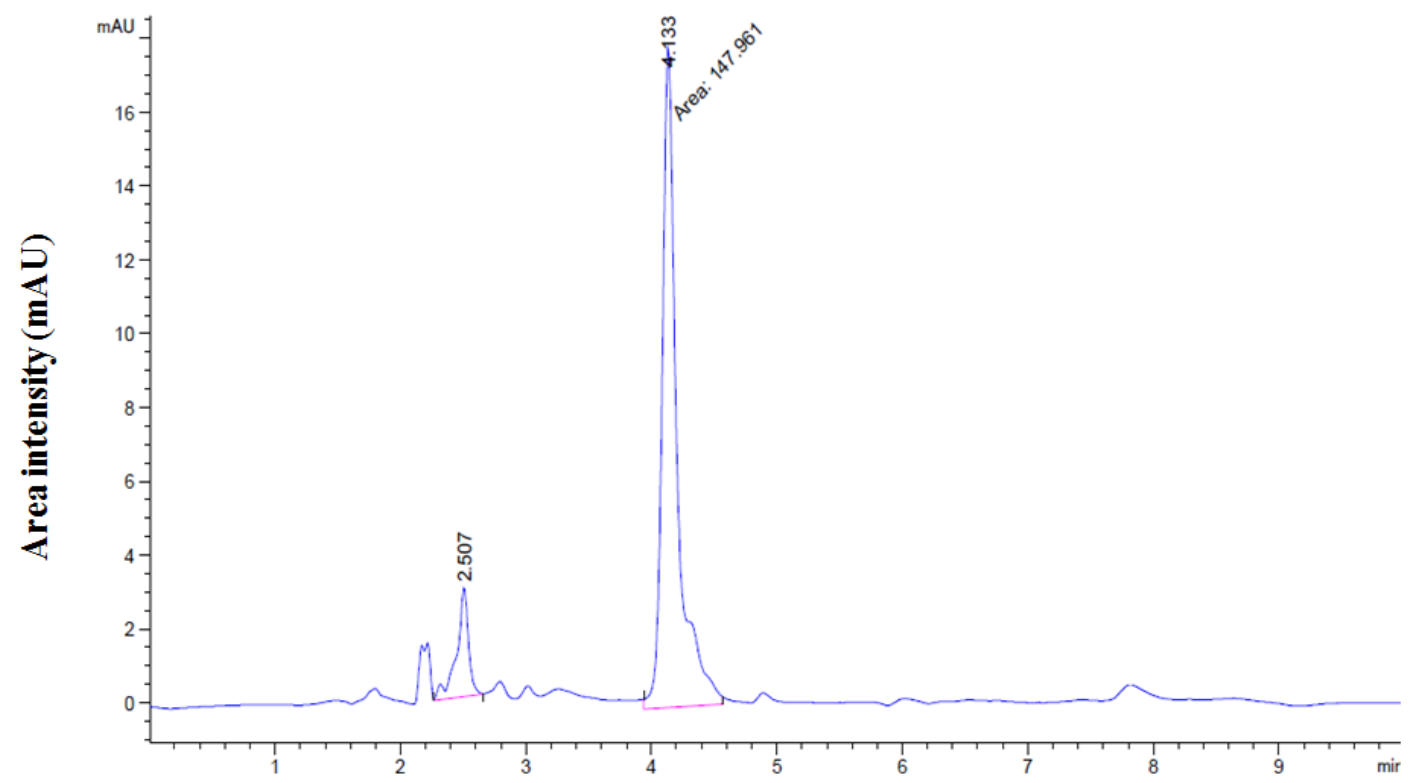

Retention time (Rt)

Fig.3 Level of cytokinins in tomato leaves

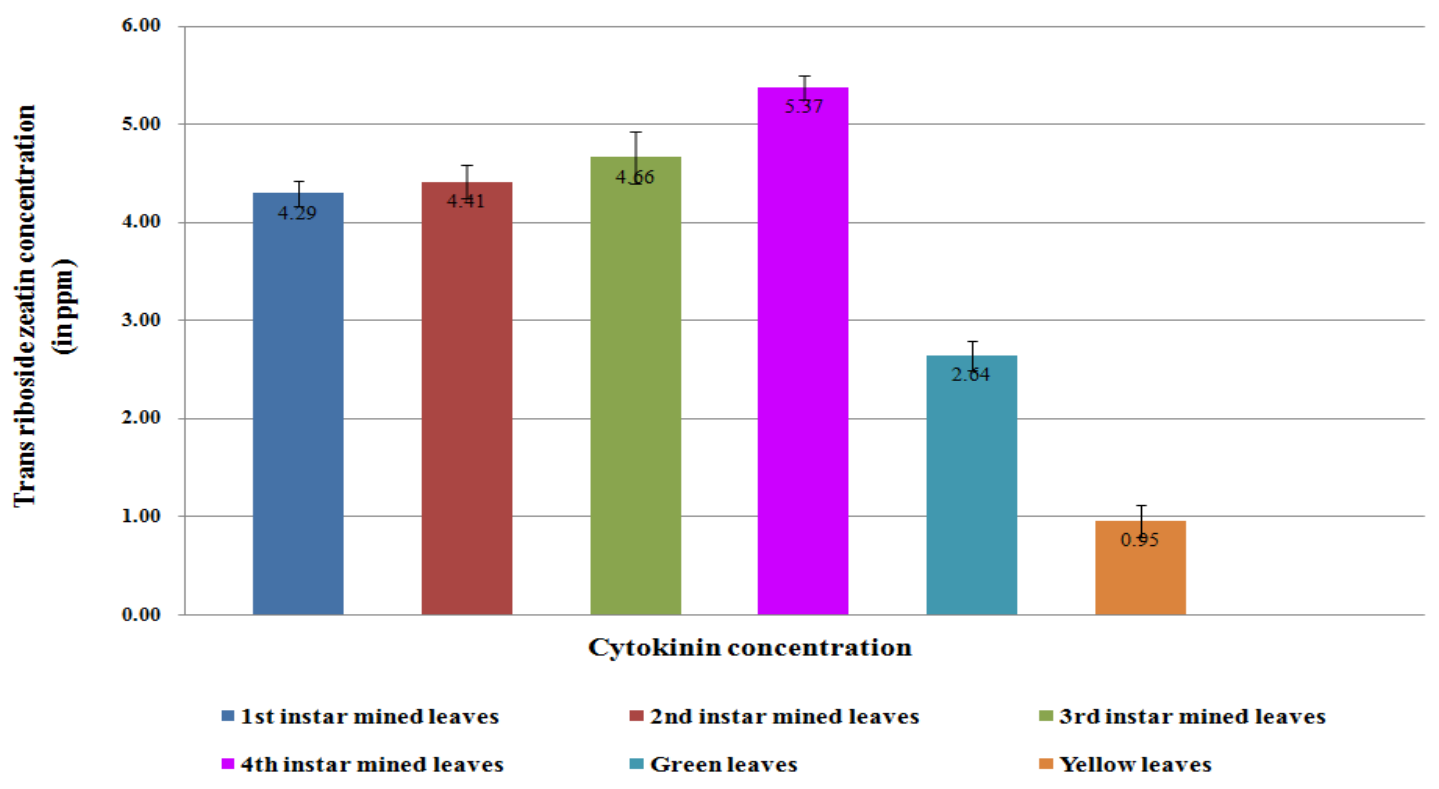


The mined regions with enriched cytokinins, allows the larvae to retain nutrients within the mine and to undergo a complete larval development. Giron et al., (2007) reported that the mined tissues exhibited similar level of proteins and sugars as green leaves. This results in net accumulation of nutrients in the mined tissues with potential competition between the plant and the mine for nutrients originating from senescing cells (change in the source-sink relationships) (Balibrea et al., 2004; Wingler et al., 2006). The perceived metabolic changes occurring in the mine and the manipulation of plant physiology induced by the insect substantiate the hypothesis that mines behave independently from the hosting leaf, operating a metabolic machinery of their own. Similar conclusions were also given for galling insects wherein they produce galling tissues with high levels of cytokinins (Leicht, 1994; Carol and Davies, 2001). In spite of great morphological differences between galls and mines, our results suggest a probable generalized process associated with the colonization of plants by endophagous organisms. Such intimate associations might have facilitated biochemical and hormonal crosstalk between insects and plants for the host plant manipulation by insects. To conclude, this phytohormone secretion helps the leafminers to generate a microenvironment with all the nutrient supply needed for their survival.

\section{Acknowledgement}

The authors acknowledge the DST-INSPIRE, Ministry of Science and Technology, New Delhi, for financial assistance to conduct the experiments.

\section{References}

Arimura, G., C. Kost, and Boland, W. 2005. Herbivore induced volatiles induce the emission of ethylene in neighboring lima bean plants. Plant J., 29, 87-98.

Balibrea, M. E., M.C.G. Garcia, T. Fatima, R. Ehneb, T. K. Lee, R. Proels, W. Tanner and Roitsh, T. 2004. Extracellular inverstase is an essential component of cytokinin-mediated delay of senescence. The Plant Cell., 16, 1276-1287.

Body, M., W. Kaiser, G. Dubreuil, J. Casas and Giron, D. 2013. Leaf-miners co-opt microorganisms to enhance their nutritional environment. Journal of Chemical Ecology, 39, 969-977.

Carol, C. M., and Davies, J. P. 2001. Cytokinins in the ball gall of Solidago altissima and in the gall forming larvae of Eurosta solidiginis. New Phytol., 151, 203-212.

Connor, E. F., and Taverner, M. P. 1997. The evolution and adaptive significance of the leaf-mining habit. Oikos, 79, 6-25.

Engelbracht, L., 1971. Cytokinin Activity in Larval Infected Leaves. Biochem. Physiol. Pflanzen (BPP), Bd.162, 9-27

Engelbrecht, L., U. Orban and Heese, W. 1969. Leaf-miner caterpillars and cytokinins in the green islands of autumn leaves. Nature, 223, 319-321.

Giron, D., E. Frago, G. Glevarec, C.M. Pieterse and Dicke,M. 2013. Cytokinins as key regulators in plant-microbeinsect interactions: connecting plant growth and defence. Functional Ecology, 27, 599-609.

Giron, D., W. Kaiser, N. Imbault and Casas, J. 2007. Cytokinin-mediated leaf manipulation by a leafminer caterpillar. Biol Lett.,3,340-343

Kahn, D.M., and Cornell, H. V. 1983. Early Leaf Abscission and Folivores: Comments and Considerations. The American Naturalist, 122 (3) : 428-432.

Kaiser, W., E. Huguet, J. Casas, C. Commin and Giron, D. 2010. Plant greenisland phenotype induced by leaf-miners is 
mediated by bacterial symbionts. Proc Soc B. 277, 2311-2319

Kumari, D.A., G. Anitha, V. Anitha, B.K.M. Lakshmi, S. Vennila and Rao N.H.P. 2015. New record of leaf miner, Tuta absoluta (Meyrich) in Tomato. Insect Environment, 20(4): 136-138.

Leicht, I. J., 1994. Induction and development of the bean gall caused by Pontania proxima. In Plant galls: organisms, interactions, population (ed. M. A. J. Williams), New York, NY: Oxford University Press. 283-300.

Meldau, S., M. Erb and Baldwin, I.T.2012. Defence on demand: mechanisms behind optimal defence patterns. Ann Bot. 110,1503-1514

Miller, P. F., 1973. The biology of some Phyllonorycter species (Lepidoptera: Gracillariidae) mining leaves of oak and beech. J. Nat. Hist. 7,391-409.

Osborne, D. J., 1973. Mutual regulation of growth and development in plants and insects. H. F. van Ernden, ed. Insect/plant relationships. Blackwell, Oxford. 33-42.
Pincebourde, S., and Casas, J. 2006. Multitrophic biophysical budgets: thermal ecology of an intimate herbivore insect-plant interaction. Ecol. Monogr. 76, 175-194.

Pincebourde, S., E. Frak, H. Sinoquet, J.L. Regnard, and Casas, J. 2006. Herbivory mitigation through increased water-use efficiency in a leaf-mining moth-apple tree relationship. Plant Cell Environ. 29, 2238-2247.

Stone, G. N., and Scho“nrogge, K. 2003. The adaptive significance of insect gall morphology. Trends Ecol. Evol. 18,512-522.

Wingler, A., S. Purdy, J. A. MacLean and Pourteau, N. 2006. The role of sugars in integrating environmental signals during the regulation of leaf senescence. J. Exp. Bot. 57, 391-399.

Zhang, H., A. Guiguet, G.Dubreuil1, A. Kisiala, P. Andreas, R. J. N. Emery, E. Huguet, M. Body and Giron, D.2017. Dynamics and origin of cytokinins involved in plant manipulation by a leaf-mining insect. Insect Science. 24, 1065-1078.

\section{How to cite this article:}

Murugasridevi K., S. Jeyarani and Mohan Kumar S. 2019. Cytokinin Induction in Response to Tomato Pinworm, Tuta absoluta Meyrick (Gelechiidae: Lepidoptera) Damage on Tomato Leaves. Int.J.Curr.Microbiol.App.Sci. 8(08): 2792-2798. doi: https://doi.org/10.20546/ijcmas.2019.808.321 